\title{
Theatre and Philosophy as Two in One in a Theoretical Issue of the Journal Anglia and a Follow-up Symposium
}

\section{Tomáš Kačer}

A review of two joint events: a publication of a Special Issue on 'Drama, Theatre, and Philosophy' (Anglia 136(1), 2018) and a Symposium Theatre and Thought in the European Tradition, University of Texas at Austin, April 6-7, 2018.

Two events took place in the spring of 2018 that offer a glimpse of the near future of theatre theory, especially when shaped and practised by scholars combining theatre studies and various other disciplines such as English studies, philosophy (particularly logic), and cultural studies. The first event was a publication of a special issue of the journal Anglia 136(1) on 'Drama, Theatre, and Philosophy', edited by David Kornhaber and Martin Middeke. The second was a symposium Theatre and Thought in the European Tradition that took place at the University of Texas at Austin on April 6-7. Most symposium participants were among the authors of the said journal issue and the symposium itself served as a forum for a follow-up discussion and confrontation over published articles (and not the other way round, as a publication of a special issue is more commonly a result of a thematic conference in the humanities).

The March 2018 special issue of Anglia is the first focusing solely on theatre in the 140-year history of the oldest existing English studies journal. Consisting of an introduction and nine articles accompanied by a solid crop of book reviews (which all without fail belong to the area of English Studies), it presents ideas by established theatre studies scholars such as Erika Fischer-Lichte, Hans-Thies Lehmann, Dan Rebellato, Mark Robson, and Dieter Thomä, and younger scholars Laura Cull Ó Maoilearca, Ramona Mosse, Tom Stern, and Anna Street. Most of the authors find themselves at home in more than one discipline. There are theatre studies scholars reaching out to English studies, cultural studies and philosophy, as well as English studies scholars and philosophers finding their materials in the theatre studies proper. Such mixture is a promise of an imaginative approach to recent theatre theory and especially philosophy - of theatre, at the theatre, and in relation to it.

Indeed, both editors, Kornhaber and Middeke, embody in their works that multifaceted coexistence of theory/philosophy on the one hand and drama/theatre on the other. Kornhaber's recent book The Birth of Theater from the Spirit of Philosophy (2016) presents a variety of presence of Nietzschean and Modernist thought in modern theatre and in dramatic works by Strindberg, Shaw, and O'Neill. For Kornhaber, drama and philosophy, theatre and 
theory, are inseparable and one always adds to a better understanding of the other. Middeke's meta-theoretical approach to recent developments in theory and philosophy has contributed to his methodological pluralism, which is the starting point of the special issue. As he writes in his 2016 collection Theory Matters, there 'seems to be no unifying paradigm which could serve as a platform for dialogue between the various theoretical interests' (MIDDEKE and REINFANDT 2016: 1), yet a voice for each is crucial and grasps a different area of the vast field of dramatic literature and theatre. Kornhaber and Middeke together believe that a study of recent thought (especially philosophy) in combination with recent cultural practices (especially theatre) opens up a possibility to question the world as we know and experience it: 'Reading a text, watching a play, or participating in a performance always entails ... the dislocation of norms, meanings, (normative) expectations, and previous knowledge' (KORNHABER and MIDDEKE 2018). An understanding of these processes emancipates the reader, spectator and participant, as these activities are never passive, but always co-creative.

The special issue asks the question of what theatre is when considered from the perspective of philosophy and how has that shifted recently but also, how does theatre change our perception of what philosophy is, especially when the two interact both on the page and stage. Cull is looking for a philosophy of theatre that takes into account theatre's recent developments and offers a non-definitional approach championed by François Laruelle. Fischer-Lichte and Lehmann present to the reader fascinating case studies of philosophical productions in history and in the present.
Street offers to seriously consider comedy as the truly philosophical paradigm of the theatre, while Rebellato, Stern and Mosse consider various aspects of theatre productions that challenge traditional views of presenting thoughts on stage. Robson and Thomä are concerned with the social impact of theatre and philosophically reflect upon theatre as a form of political activism.

All articles add fresh perspectives to their respective areas of drama/theatre, theory/philosophy and their variously intertwined relations. Their pluralistic voices participate in a virtual discussion in the reader's imagination. Yet Kornhaber and Middeke decided to take this one step further and organised a symposium, where corresponding (or, opposing) views were confronted by their respected authors. The meeting in Austin, Texas in April 2018 was scented with the smell of the freshly of the press copies of the journal. Most authors arrived and commented to their discussion partners' papers, rather than repeating what they had just published. Speaking about their colleague authors' texts and not their own, under the careful supervision of moderators, helped raise further questions and illustrate principles of the relations between theory and cultural practices on a more general level. Lehmann began the two-day discussion with a reminder that "theatre is thinking in spatial-temporal manifestations, not in story and ideas' or, in other words, it is thinking in pictures and sounds. There was a general agreement that in order to understand theatre, it is necessary to take all of its possible forms into account, for to 'limit our understanding [...] to artistic theatre only is backward-minded' (Lehmann, in discussion). In Lehmann's view, the concept 
'theatre' should be kept as a name for all the varied practices where many prefer to use 'performance'. This idea corresponds with a recurrent theme of the journal issue, the definition of theatre in relation to thought. Stern concluded that the term 'theatre' is a perfect contemporary example of Meno's paradox: one must know what theatre is before one tries to define it, and no definition will be sufficient.

Fischer-Lichte and Rebellato, who are among the authors, could not come to Austin to participate in the discussion, but were substituted by Martin Puchner (The Drama of Ideas, 2010), Freddie Rokem (Philosophers and Thespians, 2009) and Paul Woodruff (The Necessity of Theater, 2008), among others. Especially Puchner and Woodruff's keynotes opened up a very general discussion of how theatre in the broadest sense takes part in a theoretical grasping of the cultural reality. The most productive material for a recurring debate in various context was the recent tragic Stoneman Douglas High School shooting in Parkland, Florida, on February 14, 2018, and the subsequent political activism by the surviving students, many of whom were actors in a high-school production. Their identity as actors was used both to support them in their efforts and to undermine their public presence as inauthentic - merely acted. In the context of this pressing contemporary issue, the relation of theory/philosophy and drama/theatre proved to be a crucial point to grasping a variety of processes included in a social movement that aspires to transform a nation.

\section{Bibliography}

KORNHABER, David. 2016. The Birth of Theater from the Spirit of Philosophy. Nietzsche and the Modern Drama. Evanston: Northwestern University Press, 2016.

KORNHABER, David and Martin MIDDEKE (eds.). 2018. Special Issue: 'Drama, Theatre, and Philosophy'. Anglia 136(1), 2018, e-publication.

MIDDEKE, Martin and Christoph REINFANDT (eds.). 2016. Theory Matters. The Place of Theory in Literary and Cultural Studies Today. London: Palgrave Macmillan, 2016. 